\title{
Gross and Microscopic Studies on the Stomach of Domestic Duck (Anas platyrhynchos) and Domes- tic Pigeon (Columba livia domestica)
}

\section{Said A. Hassan, Eid A. Moussa}

Department of Anatomy and Embryology, Faculty of Veterinary Medicine, Suez Canal University, Ismailia, Egypt

\section{Abstract}

Ten adult domestic Mallard ducks and ten adult domestic pigeons of both sexes were used for morphologic and histological study. The proventriculus was the last part of the foregut. It was cone-shaped in pigeon while it was tubular in duck and arose from the esophagus. The ventriculus was biconvex lens in shape. It joined the proventriculus by cardiac sphincter and joined the hind gut by the pyloric sphincter. The thick muscular wall consisted of the crassuscaudodorsalis, crassuscranioventralis muscles, tenuiscraniodorsalis and caudoventralis. The inner aspect of the ventriculus in both species was lined by a hardened membrane, the cuticula gastric. For the histological study, samples from the proventriculus and of the ventriculus were stained routinely with H\&E, periodic acid-Schiff (PAS) and Masson's trichrome stain. The mucosal surface of the proventriculus has proventricular papillae over its entire surface with variable density between the two species. The proventriculus and ventriculus in both duck and pigeon have folds of the tunica mucosa lined by columnar epithelium in duck while it is cuboidal in pigeon. Simple tubular glands occupied the lamina propria of both chambers. The ventricular glands were lined by simple cuboidal cells. The proventricular glands were situated between the inner and outer layers of the lamina muscularis mucosae. The tunica submucosa was very thin in the proventricular wall while in the ventriculus, it was not separated from the lamina propria due to the absence of any lamina muscularis mucosae. The tunica muscularis of the proventriculus was formed by a thick inner layer of circular smooth muscle fibres and a thin outer layer of longitudinal fibres. In addition to these layers, oblique muscle fibres formed the most internal layer of the tunica muscularisin the ventriculus. 


\section{Keywords:}

Stomach, duck, pigeon, histology

\section{Introduction}

The Mallard is widely distributed across the Northern Hemisphere, North America from southern and central Alaska to Mexico, the Hawaiian Islands, and across Eurasia, from Iceland and southern Greenland and parts of Morocco (North Africa) in the west, Scandinavia to the north, and to Siberia, Japan, and China in the east (Cramp, 1977). The Mallard is omnivorous and very flexible in its foods choice. Its diet may vary based on several factors, including the stage of the breeding cycle, short term variations in available food, nutrient availability, and inter- and intraspecific competition (Krapu et al. 1992). Pigeons are distributed everywhere on Earth, except for the driest areas of the Sahara Desert, Antarctica and its surrounding islands and the high Arctic (Baptista et al. 1997). Seeds and fruit form the major component of the diet of pigeons. The granivorous typically feed on seed found on the ground, whereas the species that feed on fruit and mast tend to feed in trees. There are morphological adaptations that can be used to distinguish between the two groups, granivorous species tend to have thick walls in the gizzards, whereas the frugivores tend to have thin walls (Baptista et al. 1997): A significant structural difference was reported between the stomach of birds and mammals. Enough knowledge exists on the anatomy of the stomach of many other birds (Ziswiler and Farner, 1972; McLelland, 1975, 1979a; Nickel et al. 1977; King and McLelland, 1984) but, none has been published about the stomach of duck and pigeon species. Such studies would also prove useful in relation to medical, surgical, propagation and nutritional management of these birds in captivity. The purpose of this paper was to study the morphology of the glandular and the muscular stomach of the duck and pigeon.

\section{Material and methods}

Ten adult ducks and Ten adult pigeons were used. The birds were slaughtered. Carcasses were weighed to the nearest gram at postmortem. Organs were described in situ then we eviscerated the alimentary tract. The tract was stripped of fat deposits and the mesentery and the stomach was separated. The materials destined to the morphologic study were collected and the lengths of the proventriculus and ventriculus were measured and placed in a $10 \%$ formalin solution. The ventriculus was 
measured when full from the isthmus gastris to the caudal extremity of the saccus caudalis. Additionally, the height and width of the full ventriculus were measured. The height was derived from the distance between the crassus caudodorsalis and crassus cranioventralis muscles and the width was the distance between the centrum tendineum on either side of the ventriculus. The empty ventriculus (emptied of contents, washed and dried with a paper towel). Photographs were taken from one dissection of both species. A description of the gross appearance of the stomach was prepared from the written records and the photographs.

For the histological study, fragments of the stomachs were immersed in $10 \%$ formalin for 24 hours and later submitted to the dehydration process with alcohol. Histologic sections of $7 \mu \mathrm{m}$ of thickness were obtained and they were stained routinely with H\&E, periodic acid-Schiff (PAS) and Masson's trichrome stain. The sections were documented in Olympus microscope, model BX50, analyzed and described. The anatomical nomenclature used was based on Nomina Anatomica Avium (Baumel et al.,1993) whenever possible.

\section{Results}

The pigeon and duck stomach consisted of a cranial glandular compartment or proventriculus and a caudal muscular compartment or ventriculus (Fig.1, 7). The gross appearance of the proventriculus and ventriculus was similar in all species examined. The mean weight of the stomach in pigeon was $10 \mathrm{gm}$ (3.3\% from the total body weight) while in duck was $75 \mathrm{gm}$ ( $2.3 \%$ from the total body weight).

\section{The proventriculus}

The proventriculus was the last part of the foregut. It was cone-shaped in pigeon while it was tubular in duck and arose from the oesophagus (Fig 7). It was related dorsally to left lung, testis or ovary and cranial part of kidney; ventrally, medially and laterally to the left lobe of liver (Figs 4, 6). Also the spleen was located at its medial wall (Fig 6). The demarcation in pigeon was by the appearance of the surface (the surface of oesophags was smooth while that of proventriculus showed densely packed elevations which represent the proventricular glands (Fig 7). The line of demarcation in duck is the color (the color of oesophagus was whitish while that of proventriculus was light brown) (Fig 7 ) in addition to the thickness (The wall of proventriculus was thicker than that of the oesophagus). In pigeon, the caudal extent of the pro- 
ventriculus was marked by a constriction, the isthmus gastric while it was absent in duck (Fig 7). Internally, in duck there was a strong sphincter between esophagus and proventriculus while it was absent in pigeon (Figs 8, 9). Examination of the mucosal surface of the proventriculus revealed the presence of raised papillae, papillae proventricularis, over its entire surface in pigeon having base toward the surface and apex toward the lumen while in duck there were no papillae but only several openings of the ducts of the proventricular glands (Figs 8,9 ). The average number of the proventricular papillae in pigeon was $164 / \mathrm{cm}^{3}$ while in duck was 124 $/ \mathrm{cm}^{3}$. The mean length of the proventriculus in pigeon was $26 \mathrm{~mm}$ while in duck was $60 \mathrm{~mm}$. The diameter of the proventriculus in pigeon was $8 \mathrm{~mm}$ while in duck was $15 \mathrm{~mm}$.

\section{Histology}

The results of histological sections showed that the wall of the proventriculus and ventriculus consisted of four layers: a mucous membrane (tunica mucosa gastris), the submucosa (tela submucosa gastris), a muscular layer (tunica muscularisgastris) and the serosa (tunica serosa gastris). The mucous membrane (tunica mucosa) presented folds (plicae proventriculares) and sulci at its luminal surface (Figs10,
14). The folds varied in height. Some of the folds were confluent with each other. The folds were lined by a columnar epithelium, but the cells seemed to diminish in height, becoming cuboidal towards the base of the sulci. Sections stained by PAS showed a positive reaction for neutral mucin (PASpositive), especially in the upper part of the folds and the surface epithelia (Figs 11, 15). From the base of these folds, short simple tubular glands extended through the lamina propria. The glandular cell lining was similar to that of the folds lining the epithelium. The lamina muscularis mucosae consisted of an inner layer, which appeared as longitudinal smooth muscle bundles lying along the inner surface of the lobules of the proventricular glands (Figs 10,14), and an external layer of longitudinally disposed smooth muscle fibres that appeared thicker, especially opposite the areas between lobules (Figs 10, 14). The lamina propria showed many mucous glands with lymphatic infiltration. The proventricular glands occupied the main part of the proventricular wall. The lobules of the glands were conical or rounded in pigeon and elongated oval in duck and are demarcated from one another by connective tissue fibres rich in blood vessels (Figs 10 and 14). Each glandular lobule consisted 
of tubulo-alveolar units. These secretory units were lined by cuboidal to low columnar cells that were juxtaposed in their basal portions where they made contact only with adjacent cells, giving them a dentate appearance (Figs 10, 14). These cells mostly had a conical shape, with a nucleus located basally and the free surface of each cell extending into the lumen of the gland, but cells with wide straight apices and a centrally located nucleus were also seen. The collecting tubules and excretory ducts were lined by a tall, simple columnar epithelium; the glandular cells of the collecting ducts showed a dentate appearance similar to that of the glandular alveolar cells (Figs 10 and 14). However, each glandular cell group drained into the main proventricular lumen through a single mucosal papilla. The nuclei of the cells of the proventricular glands were large, round and regular. The proventricular glandular cells showed a negative reaction with the blue-PAS technique for neutral mucins but the basal lamina showed positive reaction (Figs 11, 15). The telasubmucosa was a narrow connective tissue layer sandwiched between the circular layer of the tunica muscularis and the main mass of the lamina muscularis mucosae (Fig 12). The tunica muscularis consisted of an inner circular layer of smooth muscle fi- bres and an external longitudinal layer (Figs 10,14) in duck the longitudinal layer is thicker. The tunica serosa consisted of connective tissue rich in blood vessels, a nervous plexus and adipose tissue, all covered by mesothelium. At the junction between proventriculus and ventriculus we found the absence of proventricular glands, appearance of few ventricular glands and faint eosinophilic cuticle, as well as appearance of the inner longitudinal layer of smooth muscle in duck. (Fig 13).

\section{The ventriculus}

The midgut in both birds is composed of only one region, the ventriculus. The ventriculus in both birds lay in the left caudo dorsal region of the thoracoabdominal cavity (Figs 1-6). It resembles a biconvex lens in shape (Fig 7). It joined the proventriculus by the cardiac sphincter and joined the hind gut by the pyloric sphincter. When observed ventrally, the liver and the fat laden posthepatic septum obscured the abdominal organs except most of the left surface of the ventriculus (Figs 1, 2). Its right surface related to the right lobe of the live and the descending lobe of duodenum( in pigeon the right lobe of liver cover the cranial half of the right surface of the ventriculus while in duck it cover the ventral half of the same surface) 
(Figs 1,2). In pigeon The cranial one third of the left surface is related to the left lobe of liver against the last two ribs while the caudal two thirds were against the flank coverd by the abdominal air sac (Figs 1, 3, 4). In duck the left lobe of liver covered the dorsal half of the left surface of ventriculus while the half of the same surface was against the flank coverd by the abdominal air sac (Figs 2,5,6). In duck the right lobe of liver covered a small cranial part of the left surface of the ventriculus (Fig 2). The ventriculus was ovalshaped in both species (Fig 7). It consisted of a body with 2 tapering ends, the saccus cranialis and saccus caudalis which are light red in color (Fig 7). The thick muscular walls consisted of the crassus caudodorsalis and crassus cranioventralis muscles (Fig 7) which are dark redish brown. A much thinner muscle layer, consisting of the tenuis craniodorsalis and caudoventralis muscles was present in the saccus cranialis and the saccus caudalis respectively (Fig 7 ). These muscles responsible to crush the food content of the ventriculus. The pyloric region of the stomach, connecting the ventriculus and duodenum arose from the right face of the ventriculus. The inner aspect of the ventriculus in both species was lined by a hardened membrane, the cuticula gastrica, which in pigeon appeared dark green due to the regurgitation of bile while in duck it was light green (Figs 8, 9). The color of the mucosa of Isthmus gastric was yellow in pigeon while it is whitish in duck (Figs 8, 9). Small stones and grit were found in the two species examined (Figs 8, 9). The mean length of the ventriculus in pigeon was $34 \mathrm{~mm}$ while in duck was $67 \mathrm{~mm}$. The mean width of the ventriculus in pigeon was $26 \mathrm{~mm}$ while in duck was $46 \mathrm{~mm}$. The mean hight of the in pigeon was $17 \mathrm{~mm}$ while in duck was $37 \mathrm{~mm}$.

\section{Histology}

The ventriculus of the both birds was characterized by an internal abrasion-resistant lining membrane (koilin) and a thick muscular tunic. The tunica mucosa was covered by an inner layer or 'horizontal koilin lining' which was a PAS-positive layer. The deeper layer of koilin (vertical koilin), which was trapped within the glandular epithelium, was less dense than the surface koilin in pigeon while in duck it was of same intensity (Figs 16,17,19,20). The folds of the mucous membrane were lined by columnar epithelium in duck while in pigeon it was cuboidal (Figs 16, 19). In pigeon, the cells at the tip of the epithelial folds appeared taller. The cells at the tip of the epithelial folds appeared taller and seemed to have larger secreto- 
ry vesicles in duck which stained green with Masson's trichrome stain, revealing their mucous secretions; they secret mucous which appeared mostly in the lumen and underneath the koilin lining (Fig 18). In pigeon, the cells lining the surface of the folds each showed a dark nucleus, especially in the distal and middle parts of the folds (Fig 19). Simple tubular glands extended from the lamina propria to the surface epithelium. Each tubule consisted chiefly of cuboidal cells with large, round nuclei in a basophilic cytoplasm and a few, large, palestaining basal cells (Figs 16, 19). The glandular lumina were filled with PAS-positive vertical koilin material (basal and luminal secretions) that extended to the horizontal koilin lining (Figs 17, 20). The basal ends of the glands, which were situated deeply in the lamina propria, showed great coiling (Figs 16, 19). The ventricular glands obscured most of the lamina propria, terminating at a layer of dense connective tissue known as the tela submucosa (Fig 18). The tunica muscularis in duck consisted of three layers: an internal longitudinal layer, a middle circular layer and an external layer of longitudinal smooth muscle fibres while in pigeon the inner longitudinal layer was absent ad the external longitudinal layer form most of the bulk of tunica muscularis. The mus- cle bundles were extensively surrounded by dense connective tissue fibres (Figs 16, 18, 19). The tunica serosa consisted of connective tissue and ganglionic cells of the nervous plexus that were covered by mesothelium (Figs 16, 19).

\section{Discussion}

The stomach in fowl is composed of glandular stomach (proventriculus) and muscular portion ( ventriculus or gizzard) (Suganuma et al., 1981; Macari et al. (1994) Dyce et al., 1996; Bailey et al., 1997; Bacha and Bacha, 2000), which are separated by an isthmus. The chicken stomach is at the left of the median line and is situated dorsal to the liver. In carnivorous and piscivorous fowls that swallow big victuals very little distinction exists between the glandular and the muscular stomach (Sisson \& Grossman, 1986; Baumel et al., 1993). The same results in our study, the isthmus was distinct in pigeon due to it eats small grains like Macari et al. (1994) in chicken and Bailey et al. (1997) in bustards while it is indistinct in duck due to it eats coarse food like vegetables and fish.

According to Macari et al. (1994), the avian proventriculus is a structure located between the lower esophagus and the ventriculus, lined by a glandular mucosa with 
secretory function, as found in pigeon and duck.

The longer proventriculus in duck may help with food storage like what mentioned in ratites (Angel et al. 1996).

Like our findings in pigeon, the inner surface of the proventriculus of the chicken, there is papillae, low and wide, on the lumen; on the apex of each papilla opens one of the proventricular glands (Sisson \& Grossman, 1986). Banks, 1992, Melvin and Reece (1996) as in chicken (Turk, 1982; Dyce et al., 1996) and bustards (Bailey et al., 1997). On the other hand in the duck proventriculus there are no papillae, the ducts of the proventricular glands open in depressions on the mucosal surface.

On line with the current study, Banks (1992) stated that the proventricular glands in fowl are different from those found in the mammals. The mucosa is excessively folded, forming flat folds.

The current study revealed that the mucosal epithelium of the proventriculus of both duck and pigeon was columnar and this is unlike the findings of Banks (1992) in fowl and Juliana et al. (2005) in partridge who stated that it is cuboidal.

Banks (1992) observed that the lamina propria in the proventriculus is typical and it contains numerous lymphatic tissues, which are nodular or diffuse. An interrupted layer of guided fibers forms the muscularis mucosae longitudinally, and bunches are interdigitated between the mucous glands. Submucosa occupied by numerous submucosal glands, which are compound, ramified or tubular. Juliana et al. (2005) in partridge the gland lobules separated by connective tissue septa. These findings were on line with this study in duck and pigeon. In fowl, Banks (1992) recorded that tunica muscularis is formed of inner longitudinal, middle circular and outer longitudinal layers while Juliana et al. (2005) mentioned that in partridge is formed of inner longitudinal musculature and an outer circular layer but in both birds under this study it is formed of inner circular and outer longitudinal. The tunica serosa in fowl (Banks, 1992) and partridge (Juliana et al. 2005) is composed of connective tissue and a cuboidal cells layer. The current study agreed with this in pigeon while in duck the cell layer was squamous.

Ventriculus contains the acids and enzymes secreted in the gastric proventriculus (Turk, 1982; Macari et al., 1994). Like our findings, Nickel et al. (1977) in avian, Juliana et al. 2005 in partridge as well as Bailey et al. (1997) in bustards have described muscular stomach had format of a biconvex lens lying in 
the left dorsal and ventral regions of the thoracoabdominal cavity. Chikilian and Desperoni (1996) observed that the muscular stomach of Nothura maculosa and Nothoprocta cinerascens have round format, and in Crypturellus tataupa it presents an oval format.

Baily et al. (1997) recorded in chicken that the ventriculus is constituted by four muscles, two thick and dark colored, the caudodorsalis and the cranioventralis, and two with fine thickness and clear colored, the craniodorsalis and the caudoventralis, that are responsible to crush the victuals ingested, according to the results of. These findings were on line with ours in duck and pigeon

As found in chicken (Turk, 1982; Dyce et al., 1996) and partridge (Juliana et al. 2005) we reported a white and brilliant sheet was observed in the center of the gastric ventriculus of both birds characterizing a tendinous connective tissue

Like our findings, Sisson and Grossman (1986); Bailey et al., (1997) described that the body of ventriculus separates the two tapering ends, the saccus cranialis and saccus caudalis in chicken and bustards. Nickel et al. (1977) mentioned that in the vegetarian fowls, the muscular stomach is considered as a masticator organ.
Ventriculus weights, including the cuticle, of Houbara and Kori Bustards ranged from $1.3 \%$ of body weight, which are lower compared with the Bantam Chickens where the ventriculus comprised $1.9 \%$ of bodyweight. In the present study, in pigeon was $2.6 \%$ while in duck it was $2.2 \%$ of bodyweight. The weight of the ventriculus is an expression of the development of its muscular wall, which in turn is related to the type of food consumed (McLelland, 1979a). All birds examined had stones of various sizes present in the ventriculi, probably ingested deliberately to assist with the grinding down of food.

Nickel et al. (1977) recorded that the avian ventriculus is internally lined by columnar epithelium. Tubular glands open in crypts of the epithelium. The same findings found in this study except that the lining epithelium in pigeon was cuboidal.

The inner layer of the muscular stomach of duck and pigeon is lined by a thick cuticula gastrica, with a yellowish color. The same was also observed by Suganuma et al. (1981) in wild fowls, Juliana et al. 2005 in partridge, and Bailey et al. (1997) in bustards. Dyce et al. (1996) reported that mucosa glands secretion solidifies in the surface and form the cuticula. The content of the muscular stomach of duck and pigeon was small solids, as 
grains of sand or even small stones. In birds that eat seeds, the strong contractions of the organ triturate the food with the help of ingested grains, activity that can be compared to the masticatory function of the teeth in mammals (Dyce et al., 1996). Banks (1992) stated that the lumenal surface of chicken ventriculus is lined by a proteinaceous substance similar to keratin produced by mucous glands. These findings were similar to ours in duck and pigeon. George et al. (1998) claimed that the glands produce the material of the hardened membrane of the gizzard are called koilin.

The current study recorded that there was a layer of elastic and collagen fibers is observed surrounding the ventricular mucosae, constituting the compact stratum, and externally is limited with the submucosa and these findings were in accordance with George et al. (1998) in chicken.

On line with our study, Banks (1992) reported that Tunica muscularis of the ventriculus composed a very developed inner circular layer, and a narrow outer longitudinal layer. In accordance to the current study, Bennett \& Cobb(1969) demonstrated that the muscular stomach smooth muscle is mainly disposed in crossed bunches or layers, separated by connective tissue, in relation to the other visceral muscles.
Banks (1992) in chicken was in accordance with the current study in pigeon that the serosa outer to the tunica muscularis, composed of connective tissue lined by a cuboidal cell layer while it is squamous in duck.

\section{References}

Angel CR, Scheideler SE, Sell JL (1996): Ratite nutrition. In Ratite Management, Medicine and Surgery, (ed. Tully TN, Shane SM), pp. 11--30. Florida: Kreiger Publishing.

Bacha, W.J.; Bacha, L.M. (2000): Color atlas of veterinary histology. 2.ed. Philadelphia: Lippincott Williams \& Wilkins, 318p.

Baily, T.A. et al. 1997): Comparative morphology of the alimentary tract and its glandular derivatives of captive bustards. Journal of Anatomy, v.191, p.387398,

Banks, W.J. (1992): Histologiaveterináriaaplicada. 2.ed.São Paulo: Manole,629p.

Baptista, L. F.; Trail, P. W. \&Horblit, H.M. (1997): Family Columbidae (Doves and Pigeons). In: delHoyo, J.; Elliott, A. \& Sargatal, J. (editors): Handbook of

Vol 5 No 2, (2012) 105 - 127 
birds of the world, Volume

4: Sandgrouse to Cuckoos. Lynx Edicions, Barcelona.

Baumel, J.J. et al.(1993): Handbook of avian anatomy: nomina anatomica avium. 2.ed. Cambridge: Nuttall Ornithological Club, 779 p.

Bennett, T.; Cobb, J.L.S. (1969): Studies on the avian gizzard: Morphology and innervation of the smooth muscle. Z Zell-forsch Mikrosk Anat, v.96, p.173185,

Chikilian, M.; DE Speroni, N.B. (1996):Comparative study of digestive system of three species of tinamou. I. Crypturellustataupa, Nothoproctacinera-scens, and Nothuramaculosa (aves: Tinamidae). Journal of Morphology, v.228, p.77-88,

Cramp, S. (1977):. The birds of the western Palearctic, Vol. I. Oxford: Oxford University Press. p. 505.

Dyce, K.M. et al. (1996): Anatomia das aves. In: DYCE, K.M., et al. Tratado de anatomia veterinária.2.ed. Rio de Janeiro: Guana-bara Koogan, p.631- 650.
George, L.L. et al.(1998): Histologia comparada. 2.ed. São Paulo: Roca, 286p.

Juliana R. R., Silvana M. B., Daniela O., Claudineida C., Vanessa S. F., and Alex S. (2005): Morphology of glandular stomach (Ventriculus glandularis) and muscular stomach (Ventriculus muscularis) of the partridge Rhynchotusrufescens. Ciência Rural.v. 35(6) p. 1319-1324

King AS,McLelland J (1984): Birds: their Structure and Function, 2nd Edition, pp. 84109. London: Baillie' re Tindall.

Krapu, Gary L.; Reinecke, Kenneth J. (1992): "Foraging Ecology and Nutrition". In Bruce D. J. Batt. Ecology and management of breeding waterfowl. Minneapolis: University of Minnesota Press. p.10.

Macari, M. et al.(1994): Anatomia e histologia funcional do trato digestivo. In: FUNDAÇÃO APINCO de Ciência e Tecnologia Avícolas. Fisiologia da digestão e absorção das aves. Campinas: APINCO, p.1-18.

McLelland J (1975): Aves digestive system. In Anatomy of the 
Domestic Animals (ed. Getty R), 1st edn, pp. 1857-1882. London: W. B. Saunders.

McLelland J (1979a): Digestive system. In Form and Function in Birds (ed. King AS,

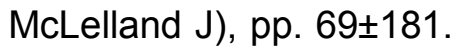
London: Academic Press.

Melvin, J.; Reece, W.O.(1996):

Dukes - Fisiologia dos animais domésticos. $11^{\text {th }}$. ed. Rio de Janeiro: Guanabara Koogan, p.390397.

Nickel R, Schummer A, Seiferle E (1977): Alimentary tract of the head.In Anatomy of the Domestic Birds (translated by Siller, WG, Wright PAL), pp. 41-72. Berlin: Paul Parey.

Romoser W.S. (1973): The Science of Entomology. New York: Macmillan Publ Co, Inc.

Sisson, S. ; Grossman, J.D (1986): Anatomia dos animais domésticos. 5.ed. Rio de Janeiro: Guana-bara Koogan, $2000 p$

Suganuma, T. et al.(1981): Comparative histochemical study of alimentary tracts with special reference to the mucous neck cells of the stomach. American Journal of Anatomy, v.161,n.2, p.219-238

Turk, D.E. (1982): The anatomy of the avian digestive tract as related to feed utilization. Poultry Science, v.61, p.1225-1244,

Wigglesworth V.B. (1972): The

Principles of Insect Physiology. London: Chapman and Hall.

Ziswiler V, Farner DS (1972): Digestion and the digestive system. In Avian Biology, vol. 2 (ed. Farner DS, King $J R)$, pp. 343 \pm 430 . London: Academic Press. 

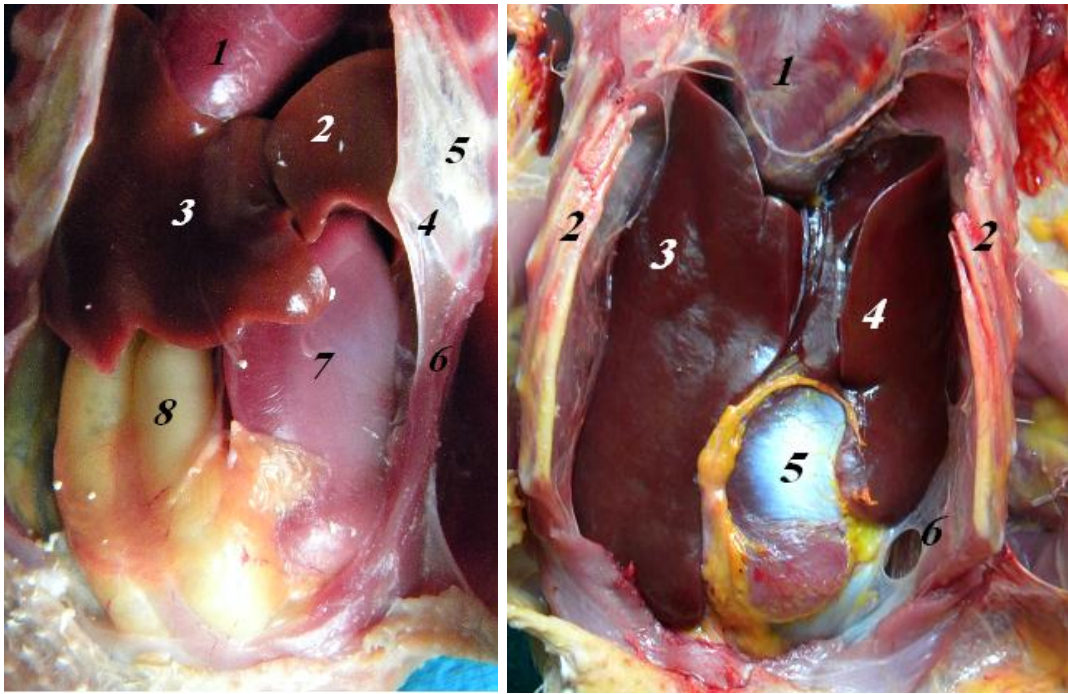

Fig (1): The ventral aspect of the viscera of a pigeon showing: 1 heart, 2 left lobe of liver, 3 right lobe of liver, 4,5 last two ribs, 6 abdominal muscles, 7 ventriculus, 8 dudenum

Fig (2): The ventral aspect of the viscera of a duck showing:

1 heart, 2 ribs, 3 right lobe of liver, 4 left lobe of liver, 5 ventriculus, 6 abdominal air sac.

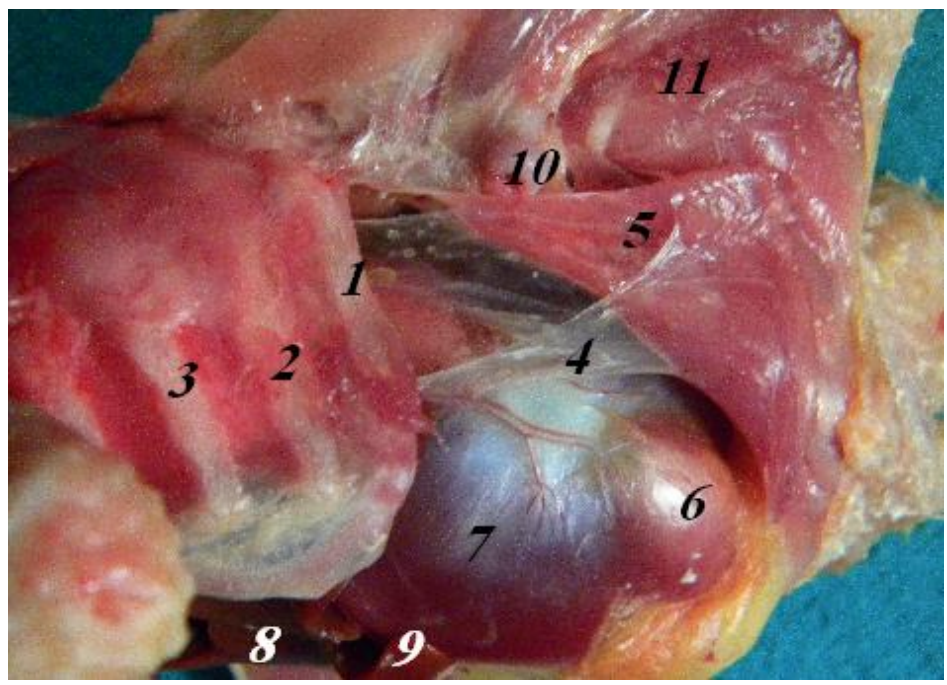

Fig (3): The left side of the trunk of a pigeon showing:

1,2,3-last three ribs, 4- abdominal air sac, 5- abdominal muscles,6- M. tenius caudoventralis, 7- M. crossuscranioventralis , 8 left lobe of liver, 9-right lobe of liver, 10-head of femur, 11- muscles of thigh 


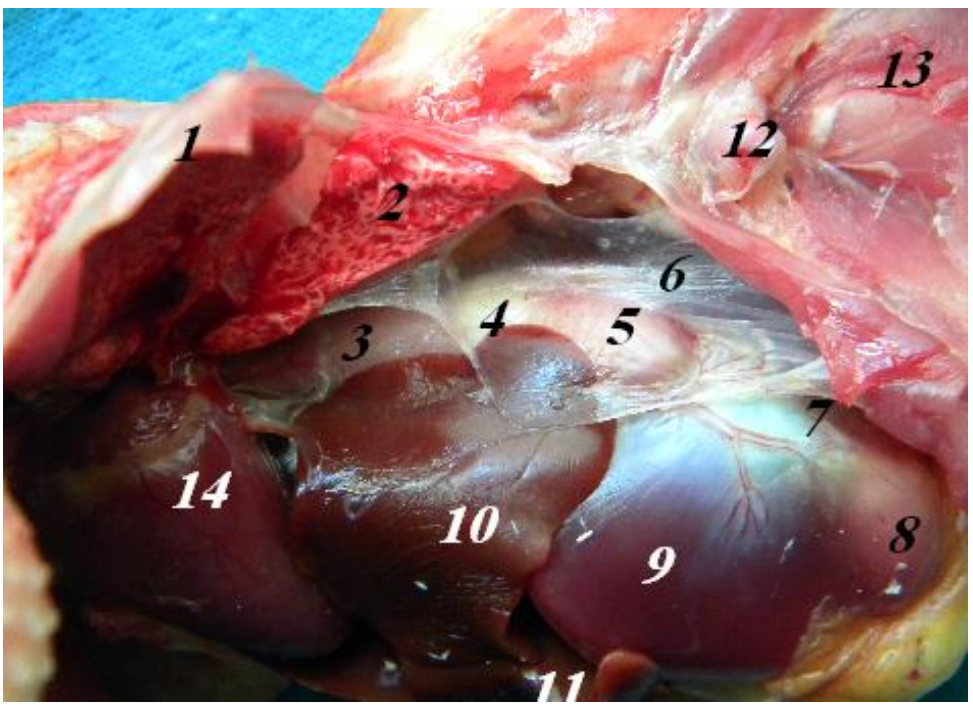

Fig (4): Left side of the viscera of a pigeon showing:

1-last rib, 2-left lung, 3- proventriculus, 4- Isthmus gastric, 5- M. tenius craniodorsalis, 6abdominal air sac, 7-M. crossus caudodorsalis, 8-M. tenius caudoventralis, 9- M. crossus cranioventralis , 10-left lobe of liver, 11-right lobe of liver, 12-head of femur, 13muscles of thigh, 14-heart

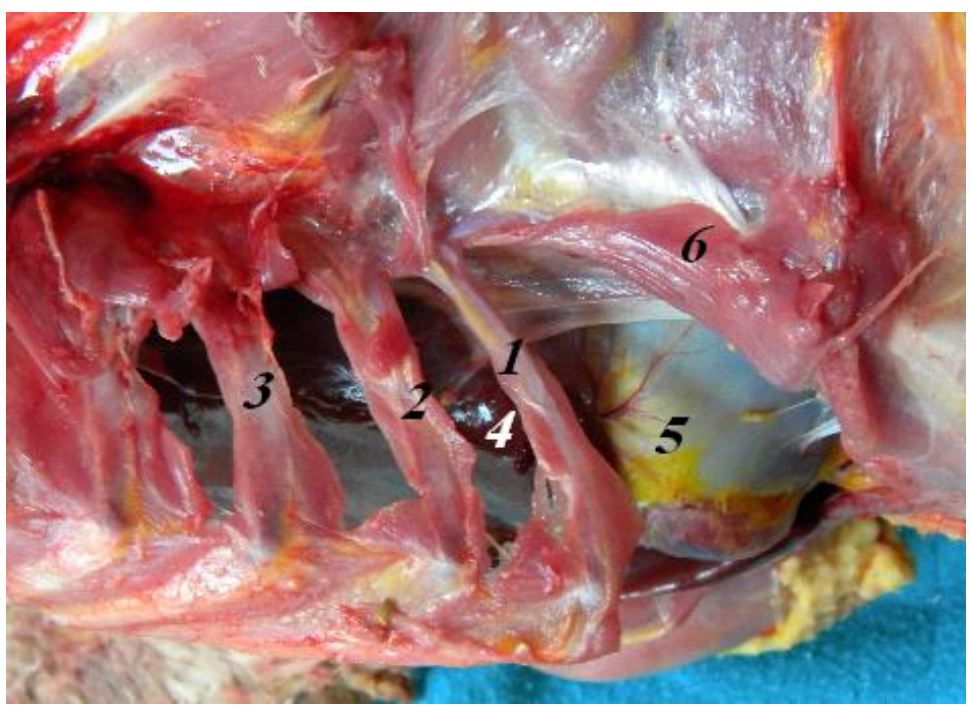

Fig (5): The left side of the trunk of a duck showing:1,2,3- last three ribs, 4-left lobe of liver, 5- ventriculus, 6- abdominal muscles. 


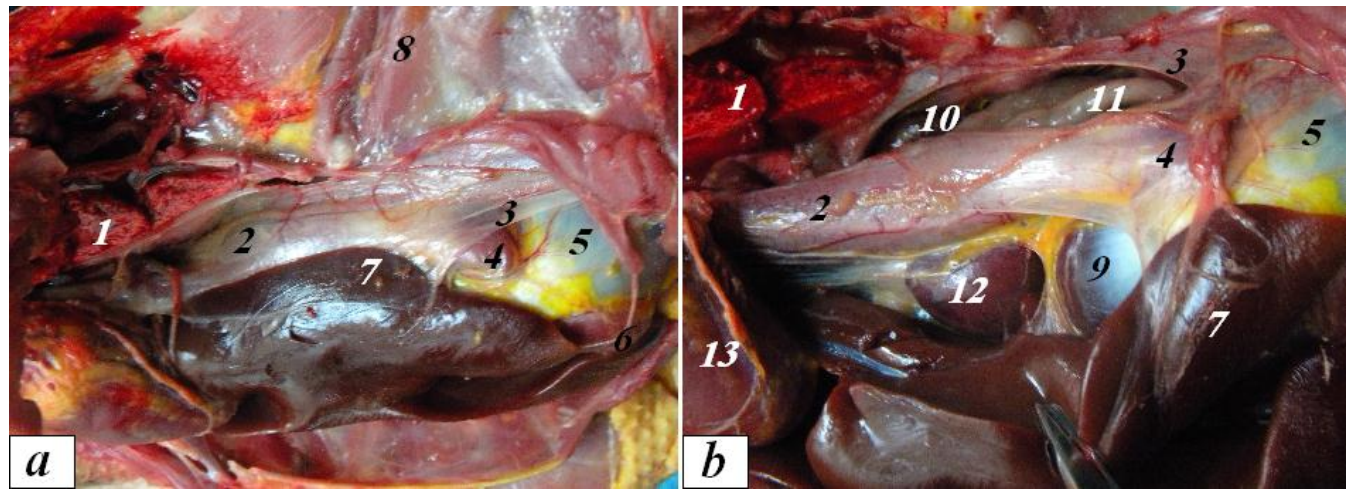

Fig (6 a, b): Left view of the viscera of a duck showing:

1-left lung, 2- proventriculus, 3- M. abdominal air sac, 4-tenius craniodorsalis 5- M. crossuscaudodorsalis, 6-M. teniuscaudoventralis,7-left lobe of liver, 8-muscles of thigh, 9-M. crossuscranioventralis, 10 left kidney, 11- left cecum, 12- spleen.
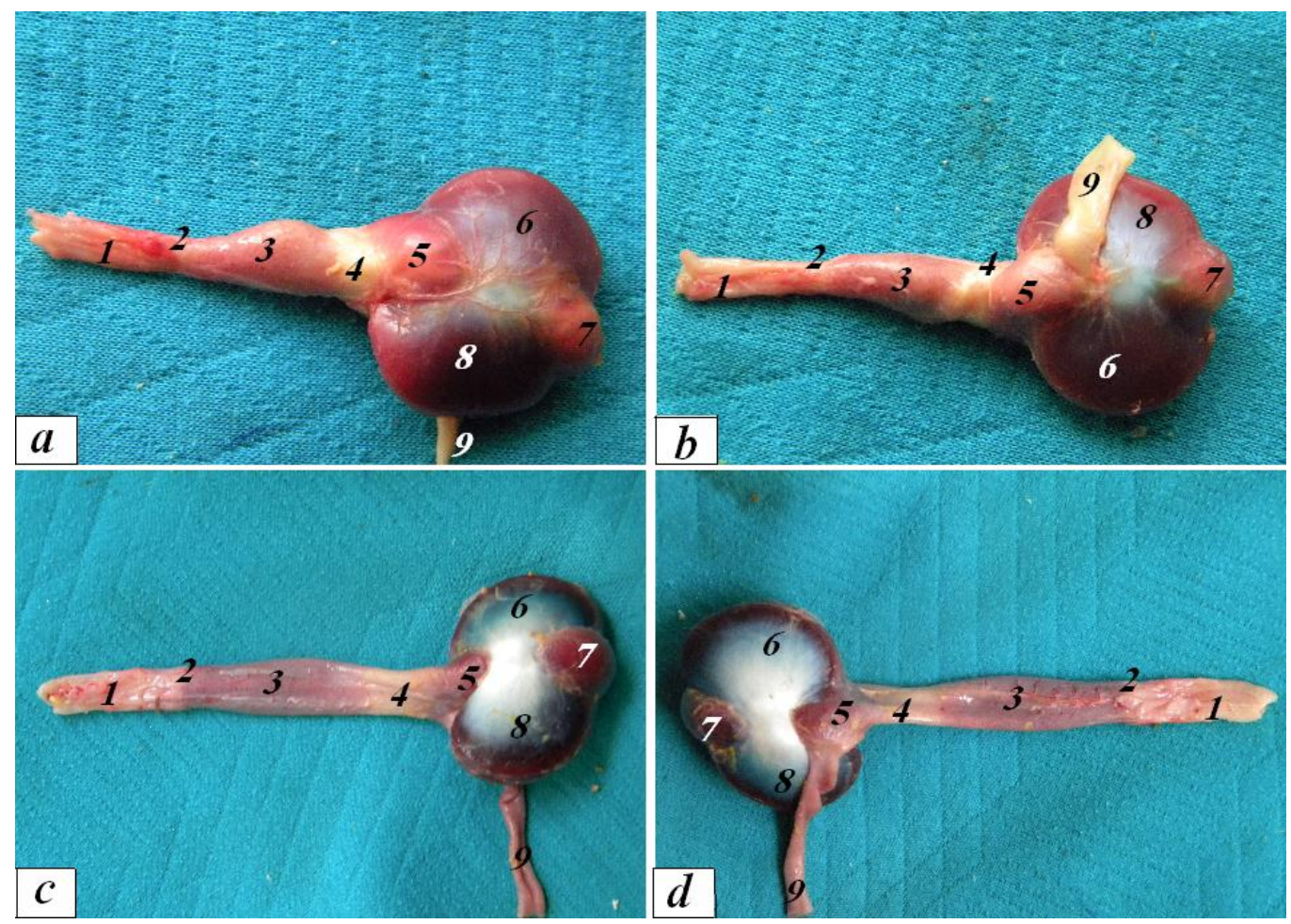

Fig (7): The intact ventriculus of pigeon (a, b) and duck (c, d) showing: 1-oesophagus,2junction between oesophagus and proventriculus , 3- proventriculus, 4- Isthmus gastric, 5- M. tenius craniodorsalis, 6-M. crossus caudodorsalis, 7-M. tenius caudoventralis, 8M. crossus cranioventralis , 9-dudenum. 

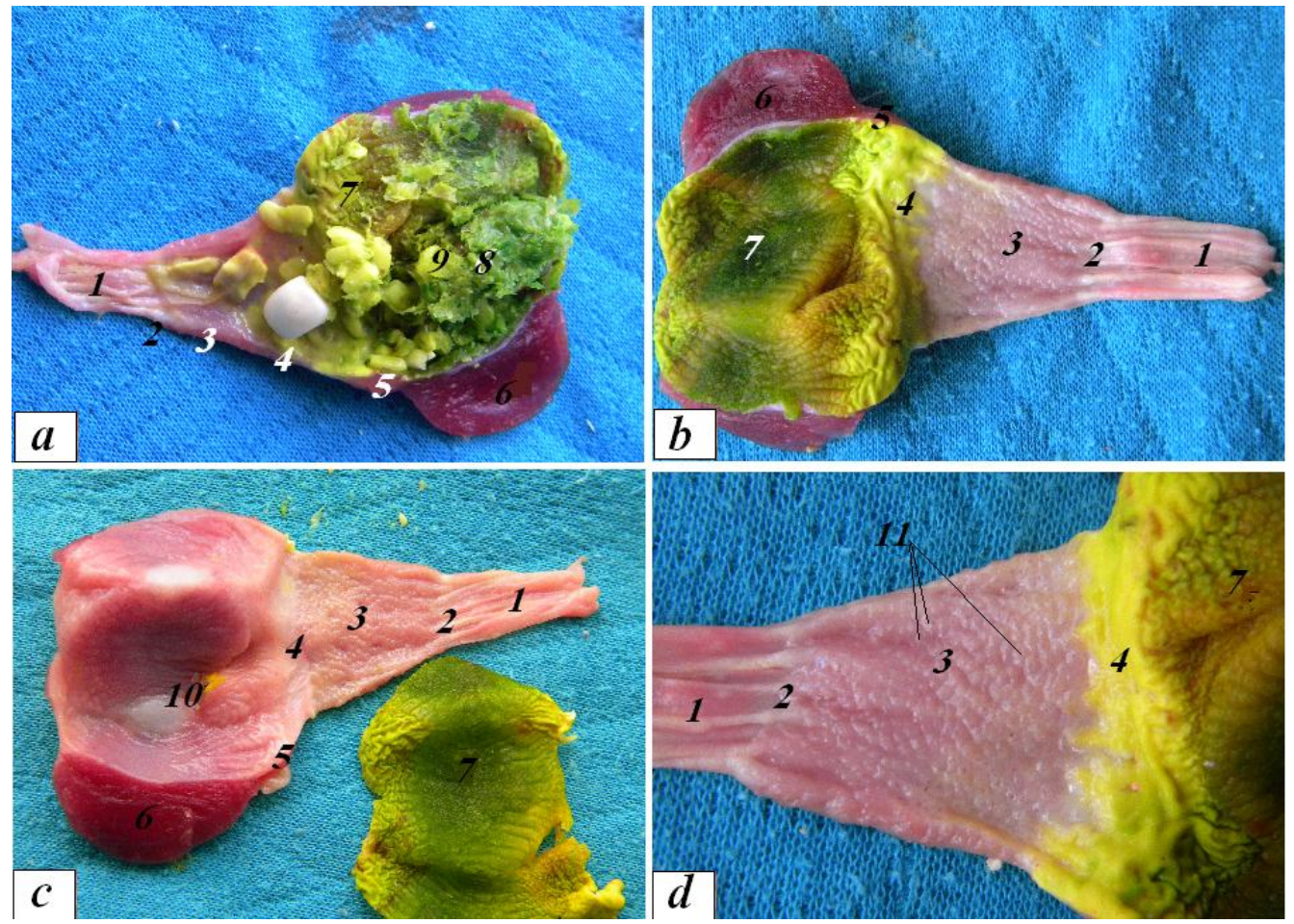

Fig (8): View of an opened ventriculus of a pigeon: a- opened stomach containing ingesta, b- the stomach after removing the ingesta, c- the stomach after removing of cuticle, d- opened proventriculus, 1-oesophagus,2- junction between oesophagus and proventriculus , 3- proventriculus, 4- Isthmus gastric, 5- M. tenius craniodorsalis, 6-M. crossuscaudodorsalis, 7- Cuticula gastrica, 8-food , 9-stones, 10-pyloric opening 

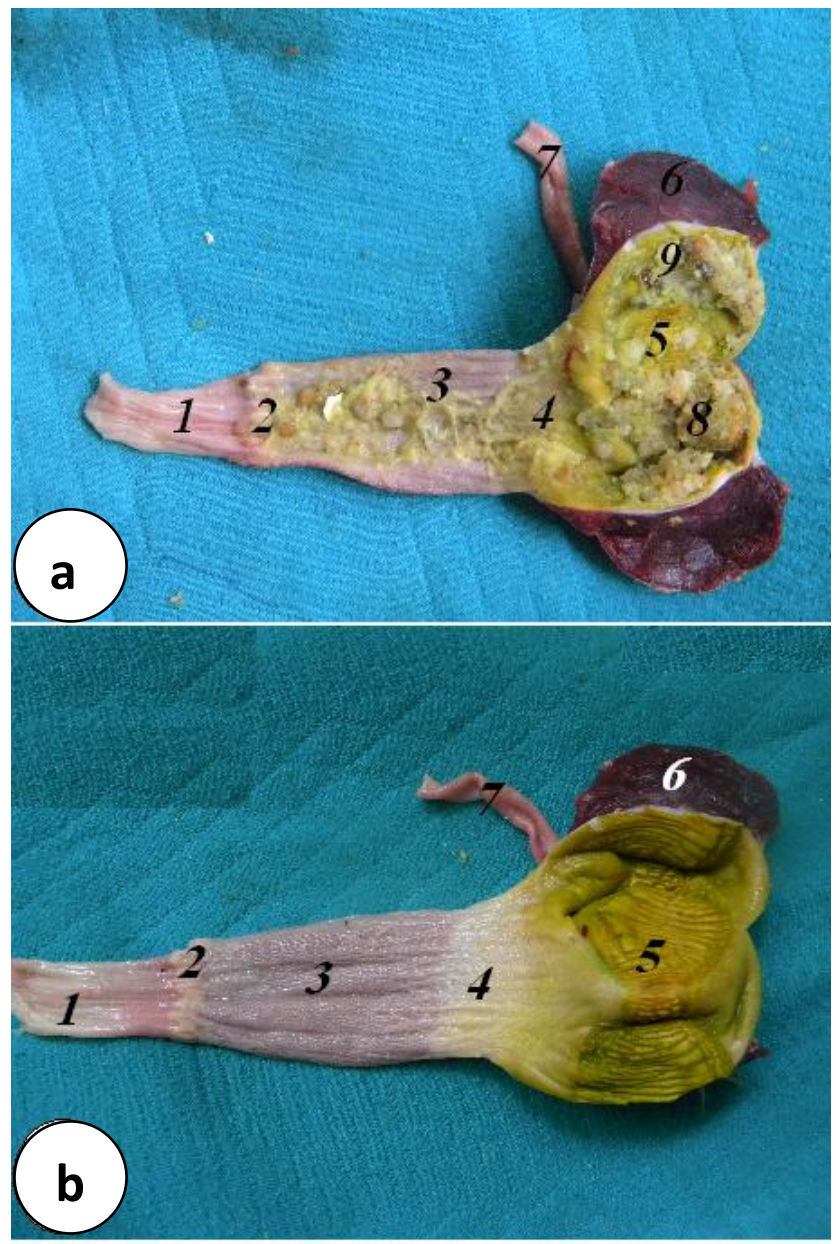

Fig (9): View of the opened stomach of a duck showing: aopened stomach with ingesta, b- opened stomach after removinf of the ingesta, c- opend oesophagus and proventriculus,1-oesophagus,2- junction between oesophagus and proventriculus , 3- proventriculus, 4- Isthmus gastric, 5- Cuticulagastrica, 6-M. crossuscaudodorsalis, 7-dudenum, 8-food , 9-stones, 10- papillae proventriculares.

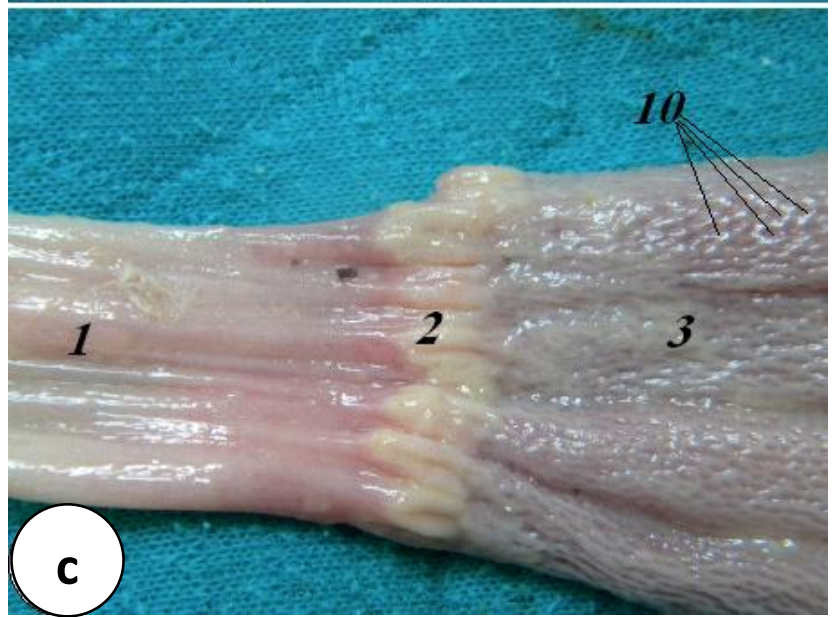




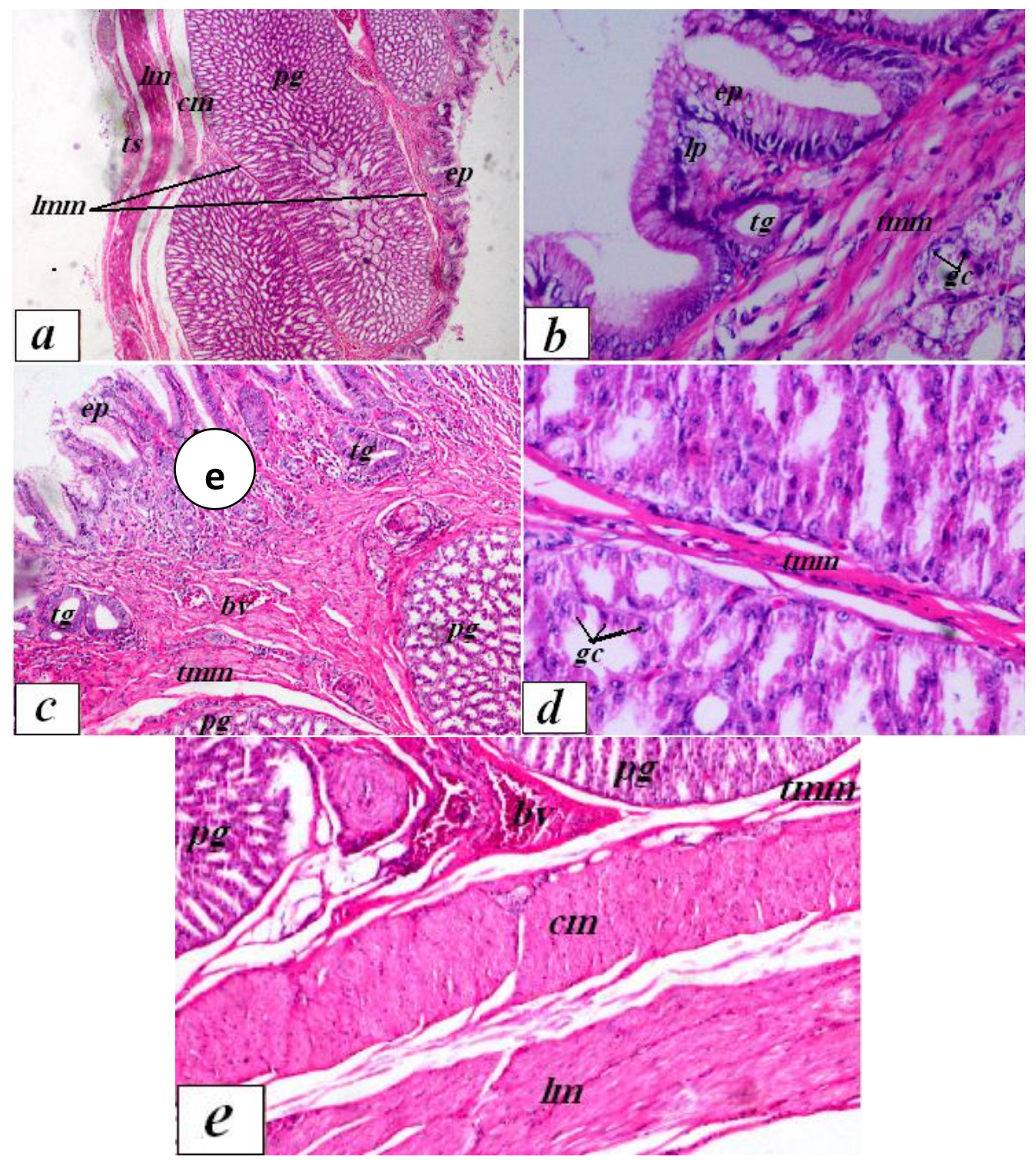

Fig (10): histological features of proventriculus of duck: a- all layers of the wall of the proventriculus (x4), b- mucosa of proventriculus (x40), c- mucosa and glands of proventriculus (x10), d- proventricular glands (x40), e- muscular layer of proventriculus (X10), ep- epithelium; pg- lobule of proventricular gland; $\mathrm{cm}$ - circular layer of tunica muscularis; Im- longitudinal layer of tunica muscularis; ts- serosa; Imm- lamina muscularis mucosae; Ip- lamina propria; tg- tubular glands; gc- glandular cells; bv- blood vessels; sm- submucosa; ct-connective tissue. H\&E 

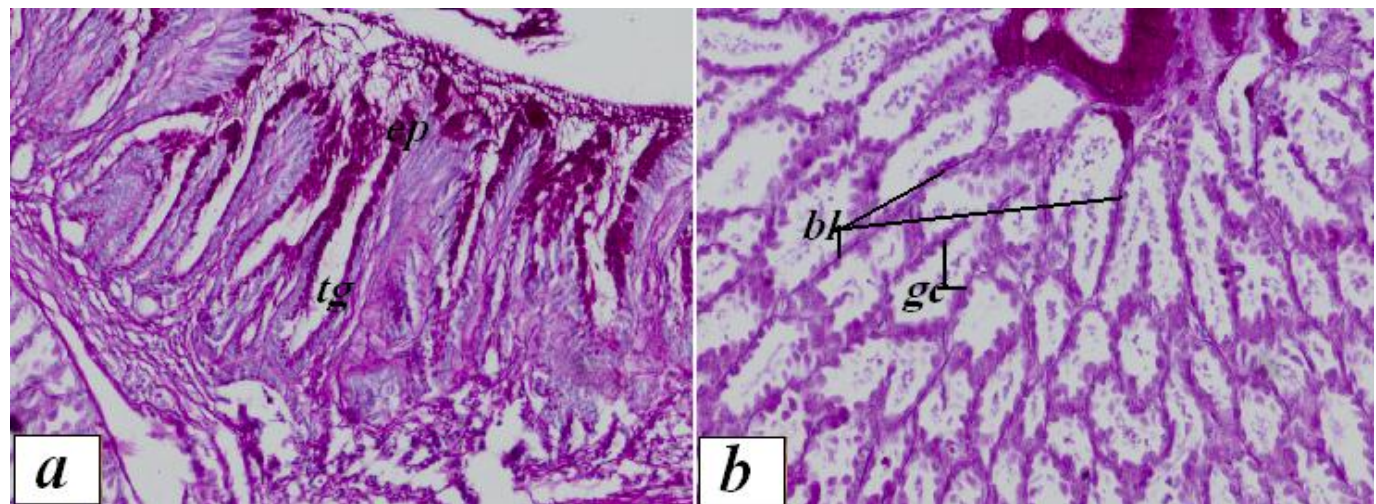

Fig (11): Proventriculus of duck: a- mucosa of proventriculus, b- proventricular glands, ep- epithelium, tg- tubular glands, gc- glandular cells, bl- basal lamina. PAS (X 40)

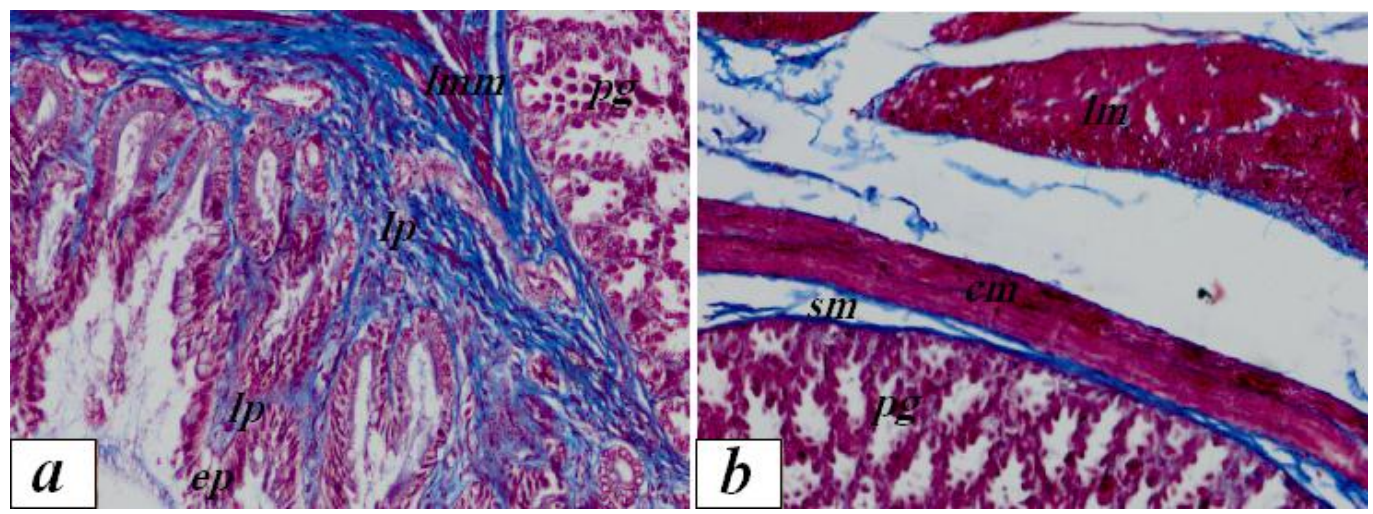

Fig (12): Proventriculus of duck: a- mucosa of proventriculus, b- muscular layer of proventriculus, ep- epithelium, pg- lobule of proventricular gland, Imm- lamina muscularis mucosae, Ip- lamina propria, cm- circular layer of tunica muscularis, Im- longitudinal layer of tunica muscularis, sm- submucosa. Masson's trichrome (X 40). 


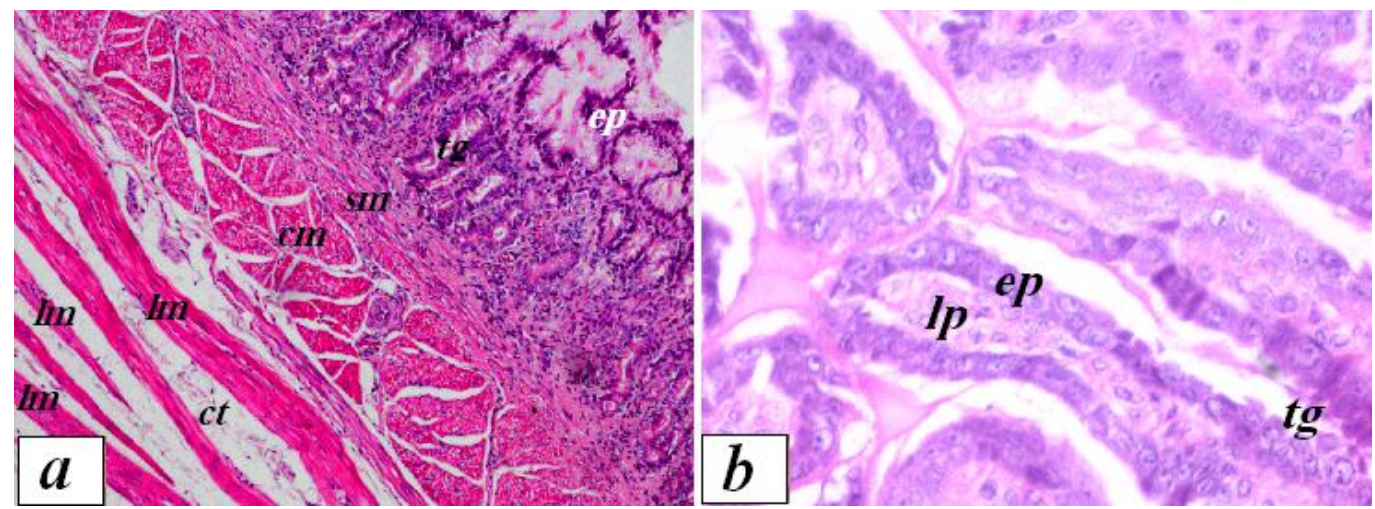

Fig (13): The junction between proventriculus and ventriculus in duck (a)(X10) and pigeon (b)(x40); ep, epithelium; cm, circular layer of tunica muscularis; Im, longitudinal layer of tunica muscularis; ct, connective tissue; ts, serosa. H\&E

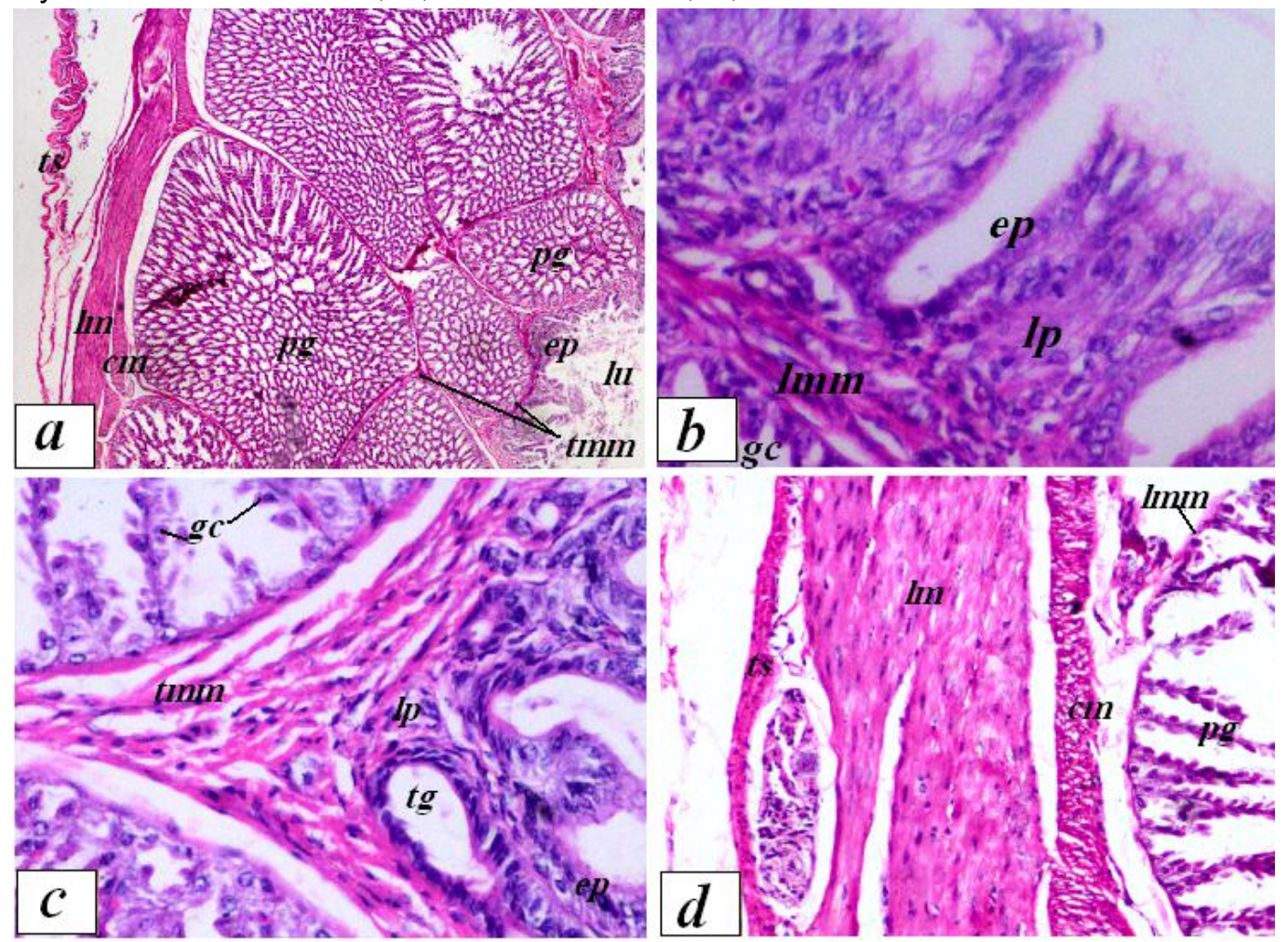

Fig (14): Histological features of proventriculus of pigeon: a- all layers of proventriculus (x4), b- mucosa of proventriculus (x40), c- proventricular glands (X40), d- muscular layer of provrntriculus (x10), ep- epithelium, pg- lobule of proventricular gland, $\mathrm{cm}$ - circular layer of tunica muscularis, Im- longitudinal layer of tunica muscularis, ts- serosa, Immlamina musculais mucosa, Ip- lamina propria, tp- tubular glands, gc- glandular cells. H\&E 


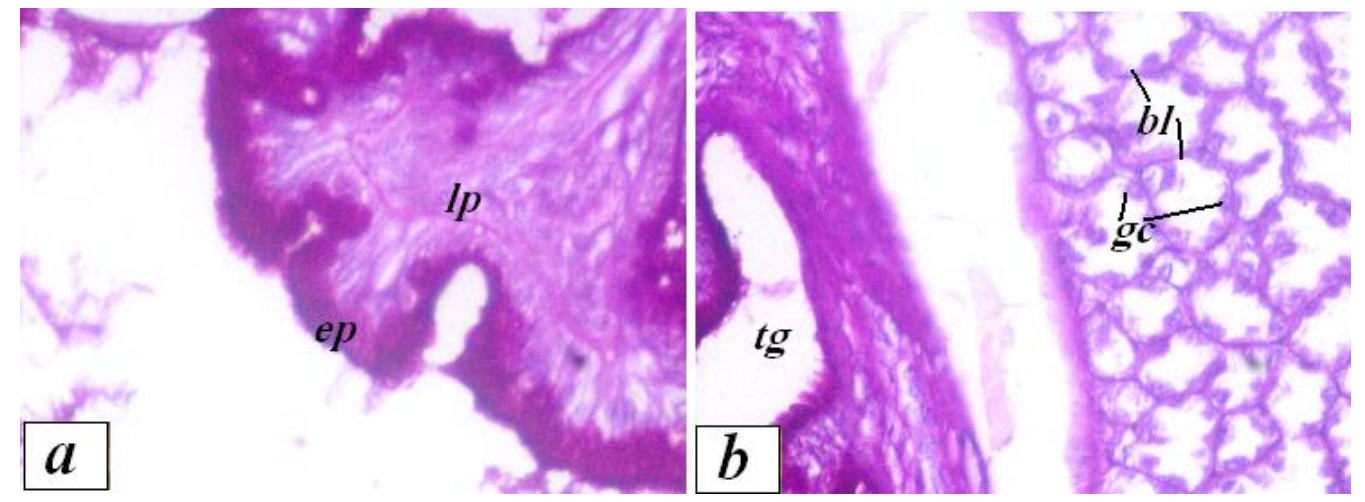

Fig (15): Proventriculus of pigeon: a- mucosa of proventriculus, b- proventricular glands, ep- epithelium, tg- tubular glands, gc- glandular cells, bl- basal lamina. PAS (X40)

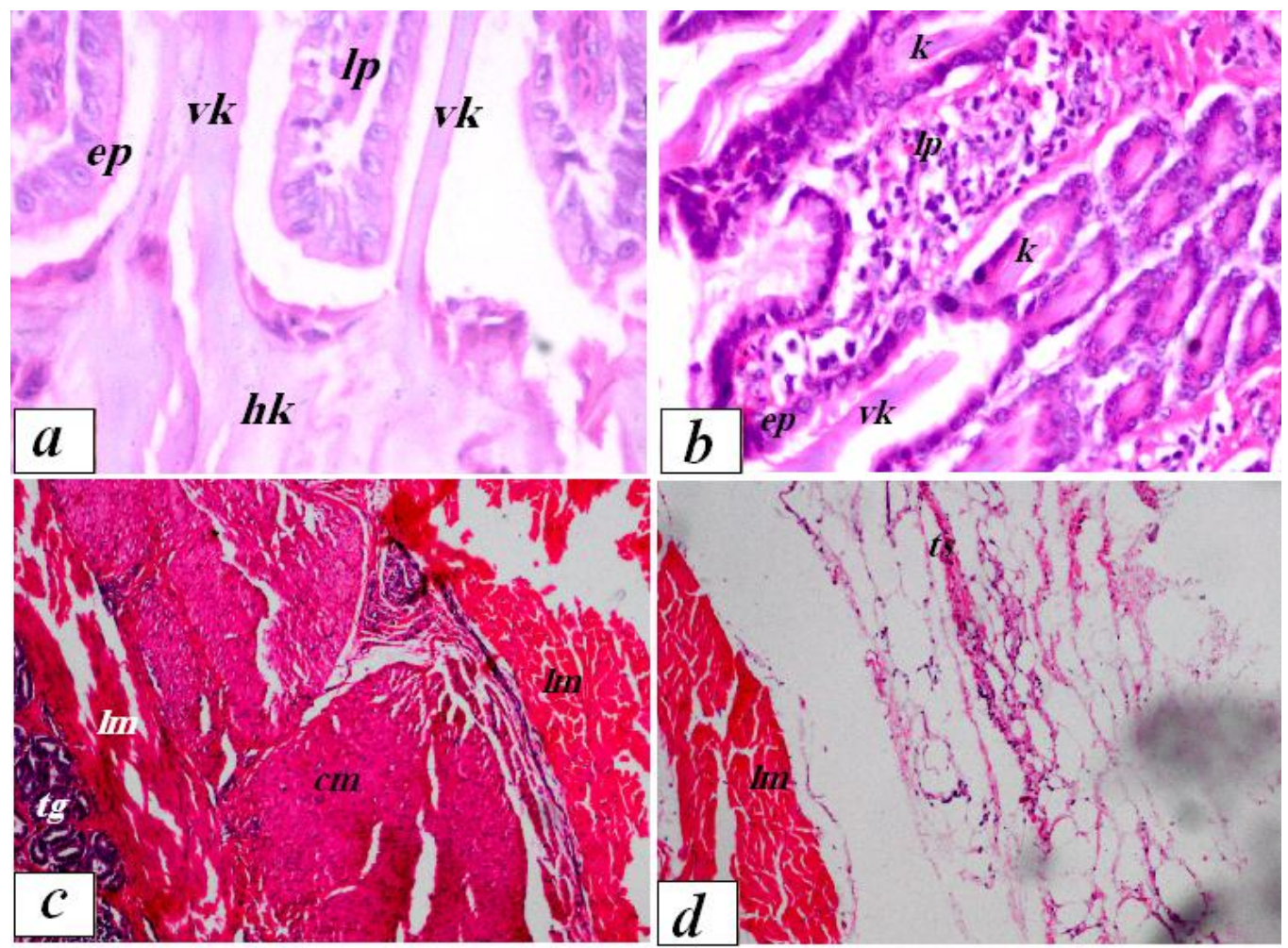

Fig (16): Histological features of ventriculus of duck: a- mucosa and koilin, b- ventricular glands, c- muscular layer, d- submucosa, ep- epithelium, cm- circular layer of tunica muscularis, Im- longitudinal layer of tunica muscularis, ts- serosa, Ip- lamina propria, tptubular glands, k- koilin substance, vk- vertical koilin, hk- horizontal koilin. H\&E (X 40). 


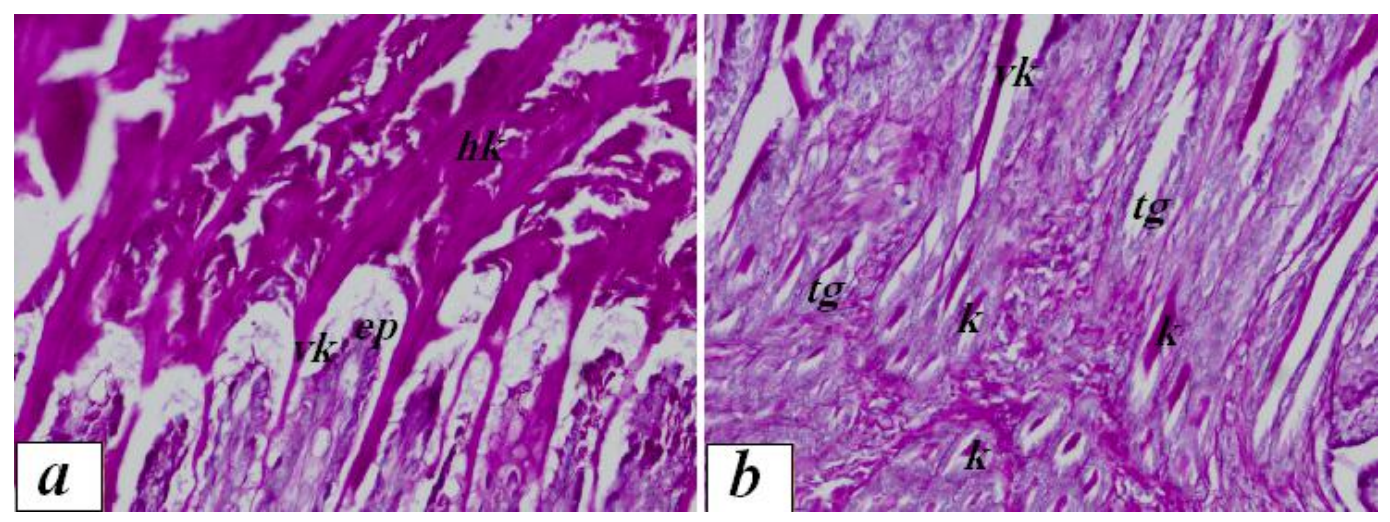

Fig (17): Ventriculus of duck: a- koilin, b- mucosa, ep- epithelium, tg- tubular glands, kkoilin substance, vk- vertical koilin- hk, horizontal koilin. PAS (X40)
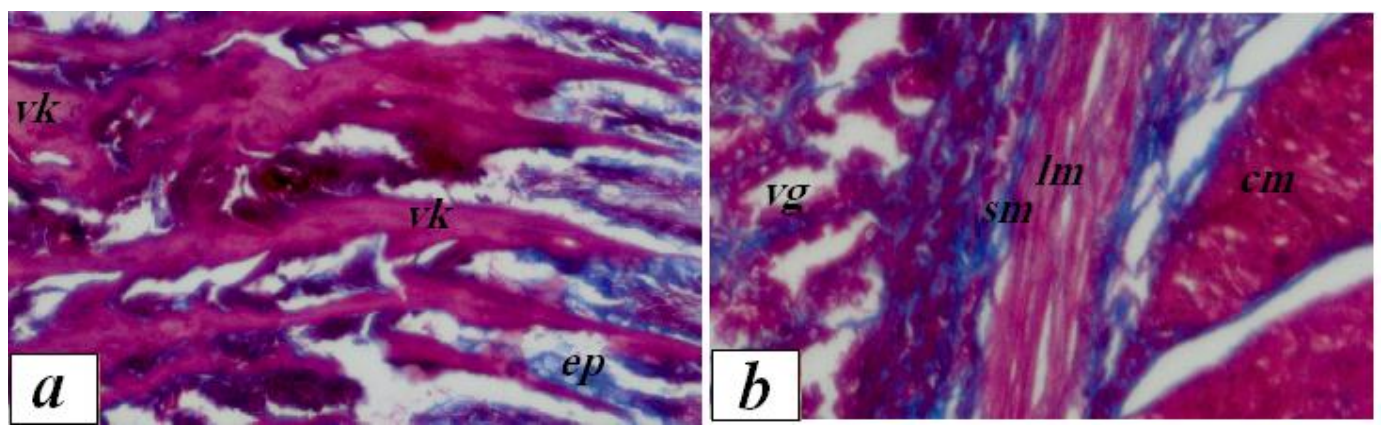

Fig (18): Ventriculus of duck: a- koiin, b- muscular layer, ep- epithelium, vk- vertical koilin, hk- horizontal koilin, cm- circular layer of tunica muscularis, Im- longitudinal layer of tunica muscularis, vg- ventricular glands, sm- submucosa. Masson's trichrome (X40) 


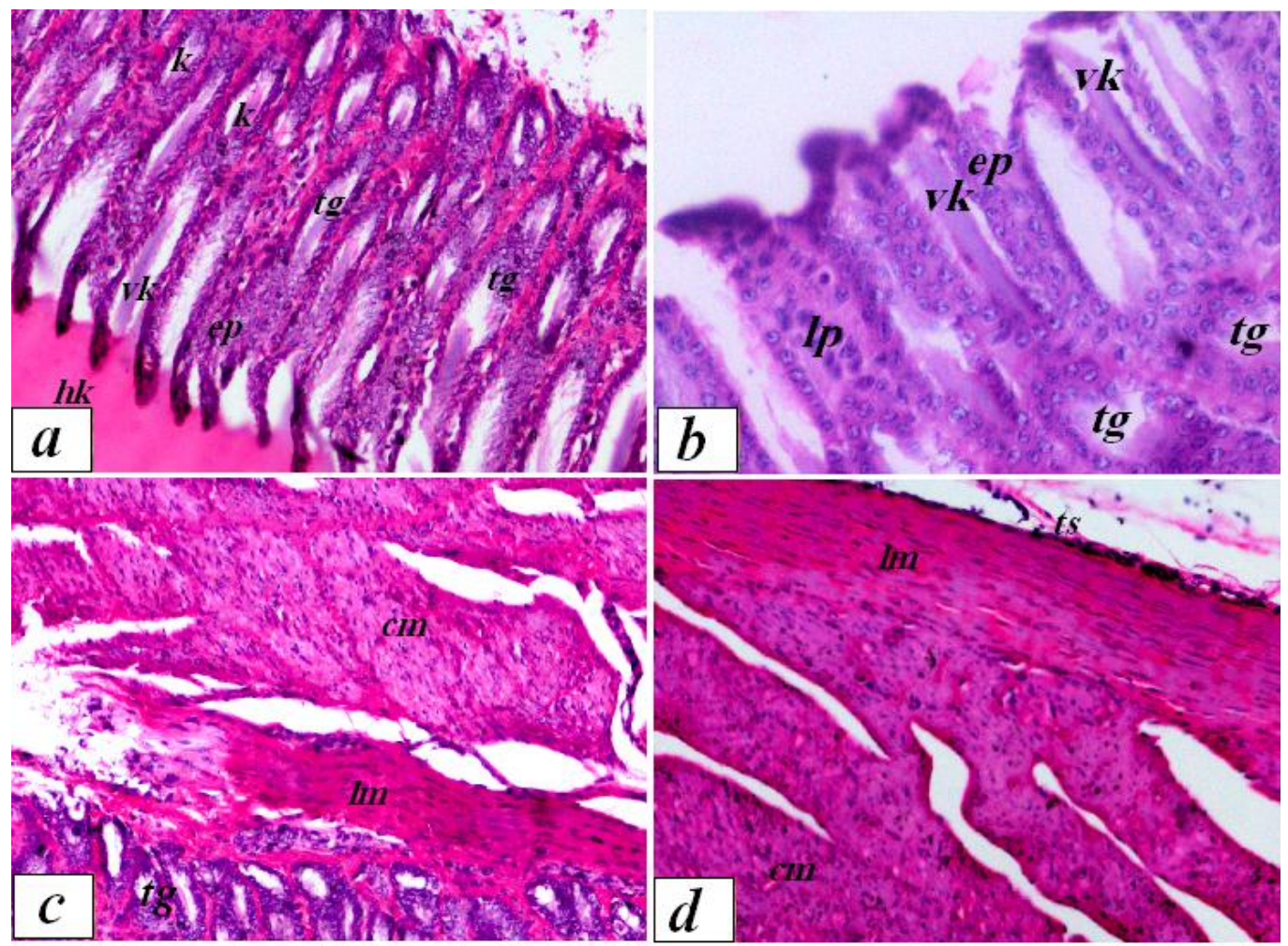

Fig (19): Histological features of ventriculus of pigeon: a- koilin and muscosa (x10), bmucosa (x40), c- ventricular gland and muscular layer (X40), d- muscular layer and submucosa (x40), ep- epithelium, cm- circular layer of tunica muscularis, Im- longitudinal layer of tunica muscularis, ts- serosa, Ip- lamina propria, tp- tubular glands, k- koilin substance, vk- vertical koilin, hk- horizontal koilin. H\&E

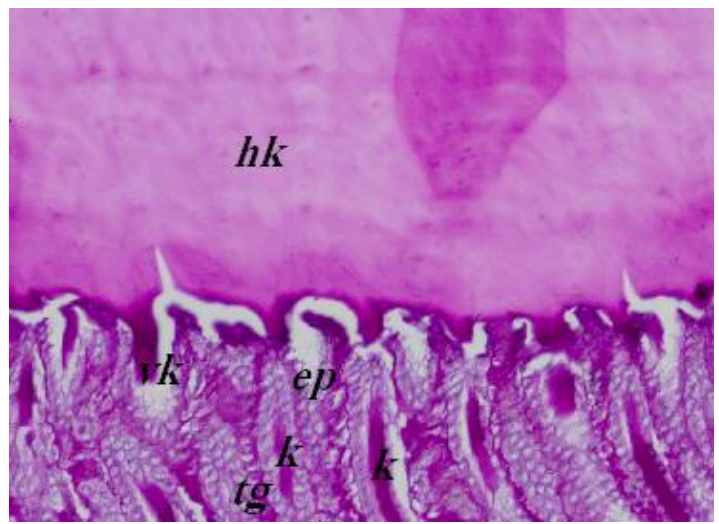

Fig (20): Ventriculus of pigeon; ep, epithelium; tg, tubular glands; k, koilin substance; vk, vertical koilin; hk, horizontal koilin. PAS(X 10) 


\section{Animal species of this issue}

\section{Water buffalo (Bubalus bubalis)}

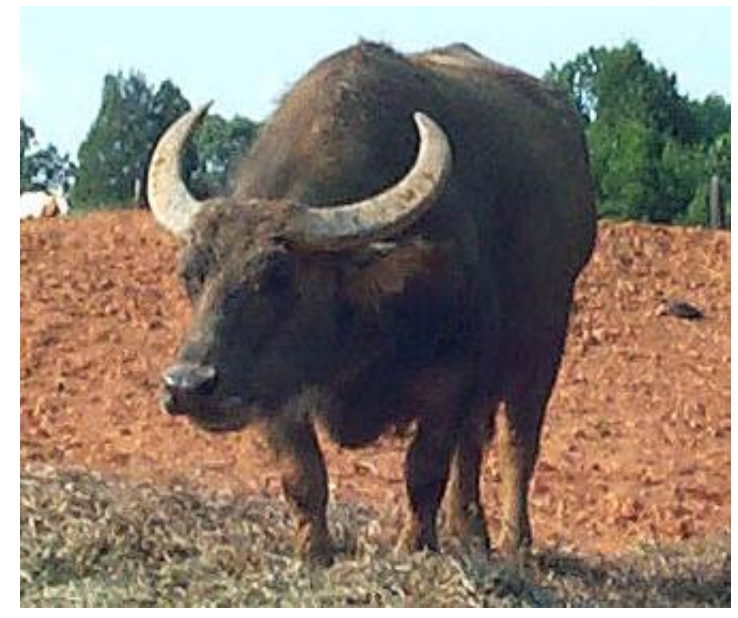

Kingdom: Animalia \& Phylum: Chordata\& Class: Mammalia \& Order: Artiodactyla \& \& Family: Bovidae \& Subfamily: Bovinae \& Tribe: Bovini\& Genus: Bubalus \& Species: B. bubalis

The water buffalo or domestic Asian water buffalo (Bubalus bubalis) is a large bovine animal, frequently used as livestock in southern Asia, and also widely in South America, southern Europe, north Africa, and elsewhere.

Buffalo are used as draft, meat, and dairy animals. Their dung is used as a fertilizer and as a fuel when dried. In Chonburi, Thailand, and in South western region of Karnataka, India, there are annual water buffalo races known as Kambala. A few have also found use as pack animals carrying loads even for special forces.

Adult Water Buffalo range in size from 400 to $900 \mathrm{~kg}$ for the domestic breeds, while the wild animals are nearly $3 \mathrm{~m}$ long and $2 \mathrm{~m}$ tall, weighing up to $1,200 \mathrm{~kg}$; females are about two-thirds this size.

River buffalo are usually black and have long curled horns, whereas swamp buffalo can be black or white, or both, with gently curved horns. The largest recorded horns are just under 2 meters long.

(Source: Wikipedia) 